\title{
In vivo study of the oestrogenic activity of milk
}

\author{
Lidia Radko ${ }^{\bowtie}$, Andrzej Posyniak \\ Department of Pharmacology and Toxicology, \\ National Veterinary Research Institute, 24-100 Puławy, Poland \\ lidia.radko@piwet.pulawy.pl
}

Received: March 30, $2021 \quad$ Accepted: August 26, 2021

\begin{abstract}
Introduction: Milk has been suggested to be a possible source of oestrogenically active compounds. In order to assess the health risk for milk consumers and ensure the safety of this staple part of the human diet, it is important to study the effect of xenooestrogen mixtures present in milk. This investigation used the available in vivo model to learn to what extent such compounds may be endocrine disruptors. Material and Methods: The recommended immature golden hamster uterotrophic bioassay was chosen. A total of 132 animals were divided into nine groups of experimental animals and positive and negative control groups, each of 12 animals. The experimental females received ad libitum either one of five samples of raw cow's milk from individual animals or one of four samples of pasteurised or ultra-high temperature treated cow's milk as retail products. After 7 days, the animals were sacrificed and necropsied. Uterine weight increases were measured as the endpoint of oestrogenic activity in milk. Results: The milk samples from individual cows and the retail milk samples did not show oestrogenic activity. However, in three groups, decreased uterine weights were observed. Conclusion: Considering that milk supplies are beneficial to health, contamination in this food should be avoided. There is a need for further animal experiments and epidemiological studies are warranted to evaluate any causative role of milk in human endocrinological disorders.
\end{abstract}

Keywords: raw milk, commercial milk, oestrogenic activity, immature females, hamster uterotrophic assay.

\section{Introduction}

Endocrine-disrupting compounds (EDCs) are a group of natural and anthropogenic substances that disrupt the synthesis, activity or metabolic lysis of sex hormones in human and animal bodies. Their effects may result in permanent changes in function or sensitivity to hormones, leading to disorders of puberty, and reproduction and even to development of hormonally dependent tumours (8). An important source of EDCs is food of animal origin, in which, apart from natural hormones there are anthropogenic equivalents and non-steroidal natural compounds $(11,31)$.

Milk is an important structural element of human nutrition worldwide. It is a source of protein with high nutritional value and many biologically active substances and is an important constituent of the daily diet. There is a body of information in the literature supporting the assertion that oestrogenic activity of milk is a new, unrecognised problem in food safety $(6,7,15$, $32,33,34,37)$. Milk is certainly an external source of hormonally active compounds in the $\operatorname{diet}(1,3,4,10,17$, $18,25,34)$. The oestrogen concentrations in milk depend on the cow's physiological condition, reaching the highest levels during late pregnancy $(10,17)$. The introduction of modern breeding methods aimed at increasing milk yield, is associated with calving cows in annual intervals and extending the milking period until the last trimester of pregnancy, when the oestrogen level in milk reaches very high concentrations (18). Prostaglandin, used for regulation and synchronisation of oestrus, also has an effect on oestrogen levels. Oestrogens in milk occur in free and conjugated form as sulphates or glucuronates. The conjugated form of oestrogen is not biologically active but can be deconjugated in the human body by bacterial or endogenous sulphatase and glucuronidase in the digestive tract. Epidemiological studies suggest a relationship between milk consumption and some reproductive and health disorders in humans $(2,20,36)$. Because oestrogens are proven risk factors for developing hormonally dependent cancers $(5,21)$ their relatively high content in milk raises concerns that a diet rich in milk may cause hormonal disorders (e.g. breast, prostate and testicular cancer, and decrease of semen quality in males) and even hormonally dependent 
cancers $(2,5,20,21,26)$. These concerns appear to be confirmed by epidemiological studies conducted in recent years, indicating a link between high milk consumption and the increased risk of the occurrence of endometrial and ovarian cancer in women (20) and prostate cancer in men (26). Food of animal origin including milk additionally may contain natural and synthetic sex steroid hormones (17 $\beta$-oestradiol, oestrone, oestriol, progesterone, medroxyprogesterone, and glucocorticoids) which are used illegally to increase cattle performance $(11,31)$. The growth promoters among these have very strong oestrogenic activity and may greatly enhance this effect in milk. Detecting steroid hormones in milk is difficult, because they are used in dairy cows in a mixture of various oestrogenic compounds in very low doses administered to the animals in the same illegal preparation as natural hormones. Milk may contain a number of other residues of active substances which are structurally diverse xeno-, phyto- and mycooestrogens $(1,3,4)$. It has been experimentally shown that the combination of different compounds can cause significant changes, even when they occur in low concentrations which individually do not cause noticeable effects.

To assess the risk to consumer health and ensure the safety of infants and children as the most vulnerable groups it is important to study the effects of xenohormones on the endocrine system using the available in vivo models. Therefore, biotests are particularly useful for assessing the total hormonal load of different diet types $(13,19)$. The rodent uterotrophic bioassay is the preferred in vivo oestrogenicity screen and is the "gold standard" for oestrogenicity study (23). The basis of the assay is the principle that the growth of the uterus in the natural oestrous cycle is controlled by oestrogens. The uterus becomes sensitive to external sources of them when the natural source of oestrogens is not available, for example because the animal is immature or ovariectomised. The Organisation for Economic Cooperation and Development (OECD) recommends the use of immature animals in order to spare mature females the surgical procedure. A second reason for favouring immature animals is past experimental outcomes suggesting that they are more sensitive than ovariectomised ones $(14,24)$.

Hendry et al. (12) showed that the golden hamster is the perfect model for perinatal endocrine disruption studies. The use of the species for uterotrophic assays indicated that these rodents are sensitive to oestrogenically active compounds to a similar extent as rats or mice (27). The usefulness of the golden hamster in a study of endocrine disruption caused by laboratory feed and milk was attested to in past studies $(27,28)$.

This study was performed with the aim of assessing the oestrogenicity of raw milk samples from individual animals (from individual farms) and commercially available processed milk and used an immature hamster uterotrophic assay which was previously found to be very sensitive to reference oestrogen agonists (27).

\section{Material and Methods}

Milk samples. Nine milk samples were studied (Table 1). Five originated from individual Polish Blackand-White cows on different individually identified farms. These farms are located in the Łęczna-Włodawa Landscape Park, which is a rural area away from industrial activity located in eastern Poland. The samples of raw milk were collected during the summer of 2016 as the cows grazed on grassland. All animals were clinically healthy and were at least two months pregnant.

Table 1. Milk sample origins and type

\begin{tabular}{cc}
\hline Sample number & Raw milk from individual animals \\
\hline 1 & Cow, 120 days of lactation \\
2 & Cow, 126 days of lactation \\
3 & Cow, 110 days of lactation \\
4 & Cow, 122 days of lactation \\
5 & Cow, 135 days of lactation \\
\hline & Retail milk \\
7 & whole-fat cow's milk, UHT \\
8 & whole-fat cow's milk, pasteurized \\
9 & reduced-fat cow's milk, UHT \\
\end{tabular}

The other four milk samples were of the processed product purchased through retail channels. The cow's milk $(n=4)$ was whole fat $(3.2 \%$ fat $)(n=2)$, reduced fat $(2 \%)(n=1)$, and fat free $(n=1)$. One sample of milk came from one producer, one deliverer and one retailer, and these were all in Poland. These retail milk samples were bought in August 2016.

Animals, housing, and diet. A total of 132 immature females of golden hamsters (Mesocricetus auratus) raised in the National Veterinary Research Institute in Puławy, Poland, were housed in polypropylene cages with non-phytooestrogen beta chip bedding at a temperature of $22 \pm 2^{\circ} \mathrm{C}$ with lighting on a light: dark cycle of $14 \mathrm{~h}: 10 \mathrm{~h}$ and humidity of $45-65 \%$. Distilled water and the Altromin 7010 certified hamster phytooestrogen-free diet (ALTROMIN Spezialfutter GmbH \& Co., Lage, Germany) were provided ad libitum. On the 15th postnatal day (PND) female pups were weaned, weighed and randomly assigned to groups (12 animals per group/cage). Test Guideline 440 issued by the OECD allows the use of 6 animals per group (23). Due to the fact that the milk or water was administered ad libitum, we increased the group size to 12 hamsters per group for all groups (experimental and control groups). The experiment was started immediately after weaning young females from their dams. At the beginning of the study, the variability in animals' body weights was minimal and did not exceed $\pm 20 \%$ of the average weight in the group. The animals were assigned to groups (both control and treated) according to randomised weight distribution. The average body weight in each group did not differ statistically from any other group (23). 
Uterotrophic assays. The immature female hamsters were given one of the nine different milk samples, water (negative control) or 17ß-oestradiol (E2) (Sigma-Aldrich, Saint Louis, MO, USA) at $100 \mathrm{ng} / \mathrm{mL}$ in water (positive control) to drink $(22,28)$, these being available ad libitum for seven days (15-22 PND) (7, 22, $28,37)$. Fresh milk, water or $17 \beta$-oestradiol solution was administered in $65-70 \mathrm{~mL}$ volumes per group (5 mL/day/animal) every morning at 8:00 a.m. All hamsters in the experimental groups drank all the milk of the kind assigned to them. Body weights were measured prior to the experiment and daily thereafter. After the last treatment at the $24 \mathrm{~h}$ point, the females were sacrificed by i.p. injection of a lethal dose of pentobarbital $(200 \mathrm{mg} / \mathrm{kg} \mathrm{b.w})$. The necropsy was carried out directly after the animals were terminated. The uterus was resected, weighed immediately (for the wet weight) and then dried at $60^{\circ} \mathrm{C}$ for at least $24 \mathrm{~h}$ and weighed again (for the dry weight).

Statistical analysis. The results are shown as means and standard deviations (SD) $(\mathrm{n}=12)$. The obtained data were analysed using the Shapiro-Wilk test for normality and Bartlett's test for confirming homogeneity of variances. The statistical significance between the mean values of the negative control group and the study groups was evaluated with a nonparametric Kruskal-Wallis test and Dunn's post hoc test. Statistical differences between parameters for hamsters given raw milk from individual cows and the same parameters for hamsters provided retail milk were assessed with the nonparametric Mann-Whitney U test.
Analyses were made using GraphPad Software (GraphPad, San Diego, CA, USA). P $<0.05$ was considered to be statistically significant.

\section{Results}

The initial body weight of the immature female golden hamsters was comparable among the nine milkconsuming groups and the negative and positive control groups (Table 2). The differences in body weight of animals between the groups were less than $\pm 20 \%$ of the mean (23).

Comparison of terminal body weights of female hamsters did not show significant changes among the study groups (Table 2). An increase in body weight of 62.0 to $89.7 \%$ in the groups of females (groups $1-5$ ) drinking raw milk from individual cows was found (Table 2). Also, an increase in body weight ranging from 76.4 to $102 \%$ among groups of animals (groups 6-9) consuming retail milk was found (Table 2). No change in animal behaviour was observed during the period of milk administration.

In all studied groups of female hamsters drinking raw milk from individual animals, no statistical increase in uterine weight was observed. On the other hand, a significant $(\mathrm{P}<0.045)$ decrease in the absolute dry weight of the uterus was noted in one group of female hamsters drinking raw milk (sample no. 2). No significant changes in the weight of the hamster uterus in the remaining five groups of animals receiving raw milk from individual animals were observed (Table 2).

Table 2. Uterotrophic effects of different kinds of milk in immature female hamsters

\begin{tabular}{|c|c|c|c|c|c|c|c|c|}
\hline \multirow{2}{*}{ Group } & \multicolumn{3}{|c|}{ Body weight } & \multicolumn{3}{|c|}{ Wet weight of the uterus } & \multicolumn{2}{|c|}{ Dry weight of the uterus } \\
\hline & Initial & Terminal & $\begin{array}{c}\text { Percentage } \\
\text { gain }\end{array}$ & Absolute (mg) & $\begin{array}{c}\text { Fold induction over } \\
\text { control }\end{array}$ & $\begin{array}{c}\text { Relative } \\
(\mathrm{mg} / 100 \mathrm{~g})\end{array}$ & Absolute (mg) & $\begin{array}{c}\text { Relative } \\
(\mathrm{mg} / 100 \mathrm{~g})\end{array}$ \\
\hline Negative control & $13.7 \pm 2.14$ & $25.2 \pm 3.54$ & 83.9 & $35.0 \pm 6.53$ & 1 & $139 \pm 12.7$ & $7.1 \pm 1.20$ & $28.1 \pm 2.60$ \\
\hline \multicolumn{9}{|c|}{ Raw milk from individual cows } \\
\hline 1 & $\begin{array}{c}14.6 \pm 1.23 \\
\mathrm{P}<0.055\end{array}$ & $\begin{array}{c}27.7 \pm 1.47 \\
\mathrm{P}<0.118\end{array}$ & 89.7 & $\begin{array}{c}33.1 \pm 3.03 \\
\mathrm{P}<0.215\end{array}$ & 0.96 & $\begin{array}{l}122 \pm 13.5 \\
\mathrm{P}<0.060\end{array}$ & $\begin{array}{l}6.2 \pm 0.71 \\
P<0.053\end{array}$ & $\begin{array}{c}22.3 \pm 3.10 \\
\mathrm{P}<0.060\end{array}$ \\
\hline 2 & $\begin{array}{c}13.7 \pm 2.61 \\
\mathrm{P}<0.832\end{array}$ & $\begin{array}{c}22.2 \pm 3.37 \\
\mathrm{P}<0.186\end{array}$ & 62.0 & $\begin{array}{c}26.1 \pm 7.98 \\
\mathrm{P}<0.066\end{array}$ & 0.75 & $\begin{array}{l}117 \pm 14.7 \\
\mathrm{P}<0.055\end{array}$ & $\begin{array}{c}4.9 \pm 1.59^{*} \\
\mathrm{P}<0.045\end{array}$ & $\begin{array}{c}22.0 \pm 3.45 \\
\mathrm{P}<0.080\end{array}$ \\
\hline 3 & $\begin{array}{c}13.7 \pm 1.72 \\
\mathrm{P}<0.908\end{array}$ & $\begin{array}{c}23.7 \pm 2.33 \\
\mathrm{P}<0.613\end{array}$ & 73.0 & $\begin{array}{c}27.9 \pm 5.62 \\
\mathrm{P}<0.060\end{array}$ & 0.80 & $\begin{array}{l}118 \pm 26.8 \\
P<0.065\end{array}$ & $\begin{array}{l}5.7 \pm 1.00 \\
P<0.070\end{array}$ & $\begin{array}{c}24.4 \pm 5.36 \\
\mathrm{P}<0.064\end{array}$ \\
\hline 4 & $\begin{array}{c}14.7 \pm 1.84 \\
\mathrm{P}<0.318\end{array}$ & $\begin{array}{c}25.4 \pm 3.20 \\
\mathrm{P}<0.999\end{array}$ & 72.8 & $\begin{array}{l}28.4 \pm 5.86 \\
\mathrm{P}<0.055\end{array}$ & 0.81 & $\begin{array}{l}112 \pm 18.1 \\
\mathrm{P}<0.074\end{array}$ & $\begin{array}{l}5.6 \pm 0.82 \\
P<0.059\end{array}$ & $\begin{array}{c}22.0 \pm 3.17 \\
\mathrm{P}<0.051\end{array}$ \\
\hline \multirow[t]{2}{*}{5} & $\begin{array}{c}14.6 \pm 1.52 \\
\mathrm{P}<0.243\end{array}$ & $\begin{array}{c}24.2 \pm 2.22 \\
\mathrm{P}<0.633\end{array}$ & 65.8 & $\begin{array}{c}28.9 \pm 4.28 \\
\mathrm{P}<0.061\end{array}$ & 0.83 & $\begin{array}{l}120 \pm 16.0 \\
P<0.061\end{array}$ & $\begin{array}{l}6.0 \pm 1.20 \\
P<0.054\end{array}$ & $\begin{array}{c}25.0 \pm 4.41 \\
\mathrm{P}<0.062\end{array}$ \\
\hline & \multicolumn{8}{|c|}{ Retail milk } \\
\hline 6 & $\begin{array}{c}13.7 \pm 2.63 \\
\mathrm{P}<0.610\end{array}$ & $\begin{array}{c}27.6 \pm 3.21 \\
\mathrm{P}<0.077\end{array}$ & 101 & $\begin{array}{l}36.6 \pm 6.33 \\
\mathrm{P}<0.305\end{array}$ & 1.05 & $\begin{array}{l}119 \pm 16.5 \\
\mathrm{P}<0.070\end{array}$ & $\begin{array}{l}6.7 \pm 0.97 \\
P<0.237\end{array}$ & $\begin{array}{c}21.8 \pm 3.00^{*} \\
\mathrm{P}<0.031\end{array}$ \\
\hline 7 & $\begin{array}{c}12.7 \pm 1.33 \\
\mathrm{P}<0.075\end{array}$ & $\begin{array}{c}22.4 \pm 2.30 \\
\mathrm{P}<0.187\end{array}$ & 76.4 & $\begin{array}{l}26.0 \pm 4.35 \\
\mathrm{P}<0.052\end{array}$ & 0.74 & $\begin{array}{l}116 \pm 17.9 \\
P<0.060\end{array}$ & $\begin{array}{l}5.0 \pm 0.82 * \\
\mathrm{P}<0.046\end{array}$ & $\begin{array}{c}22.4 \pm 3.66 \\
P<0.062\end{array}$ \\
\hline 8 & $\begin{array}{c}12.0 \pm 0.80 \\
\mathrm{P}<0.352\end{array}$ & $\begin{array}{c}22.4 \pm 1.76 \\
\mathrm{P}<0.107\end{array}$ & 86.7 & $\begin{array}{c}36.6 \pm 8.91 \\
\mathrm{P}<0.346\end{array}$ & 1.05 & $\begin{array}{l}162 \pm 25.3 \\
\mathrm{P}<0.062\end{array}$ & $\begin{array}{l}7.6 \pm 2.05 \\
P<0.266\end{array}$ & $\begin{array}{l}33.6 \pm 6.03 \\
\mathrm{P}<0.059\end{array}$ \\
\hline 9 & $\begin{array}{c}12.3 \pm 0.68 \\
\mathrm{P}<0.056\end{array}$ & $\begin{array}{c}24.9 \pm 2.24 \\
\mathrm{P}<0.949\end{array}$ & 102 & $\begin{array}{c}43.7 \pm 6.24 \\
\mathrm{P}<0.063\end{array}$ & 1.25 & $\begin{array}{l}175 \pm 17.6 \\
P<0.071\end{array}$ & $\begin{array}{l}8.0 \pm 0.33 \\
\mathrm{P}<0.088\end{array}$ & $\begin{array}{c}31.9 \pm 3.11 \\
\mathrm{P}<0.053\end{array}$ \\
\hline \multirow[t]{2}{*}{ Positive control } & $\begin{array}{c}12.6 \pm 2.81 \\
\mathrm{P}<0.355\end{array}$ & $\begin{array}{c}26.0 \pm 3.83 \\
\mathrm{P}<0.855\end{array}$ & 106 & $\begin{aligned} 127 & \pm 24.6^{* * * *} \\
\mathrm{P} & <0.0008\end{aligned}$ & 3.63 & $\begin{array}{c}493 \pm 64.9 * * * \\
\mathrm{P}<0.0006\end{array}$ & $\begin{array}{c}19.6 \pm 4.13 * * * \\
\mathrm{P}<0.0007\end{array}$ & $\begin{array}{c}76.3 \pm 11.70^{* * * *} \\
\mathrm{P}<0.0008\end{array}$ \\
\hline & \multicolumn{2}{|c|}{ Mann-Whitney test } & & $\mathrm{P}<0.058$ & & $\mathrm{P}<0.082$ & $\mathrm{P}<0.084$ & $\mathrm{P}<0.061$ \\
\hline
\end{tabular}

Data are presented as mean $\pm \mathrm{SD}$ values $(\mathrm{n}=12) ; * \mathrm{P}<0.05 ; * * * \mathrm{P}<0.001$ vs negative control. The Mann-Whitney test was used to compare the statistical differences between raw milk from individual cows and retail milk 
In all studied groups of female hamsters drinking retail milk, no statistical increase in uterine weight was observed. However, the fold induction over the negative control absolute wet weight of the uterus was 1.25 in the group which received raw milk (sample no. 9). A statistical decrease in absolute dry uterine weight $(\mathrm{P}<0.046)$ was observed in a group receiving retail milk (sample and Group no. 7). In another group given similar milk (sample no. 6), a statistical reduction $(\mathrm{P}<0.031)$ in relative dry weight of the organ was noted (Table 2 ).

There were no differences between the analysed weights of the uteri of hamsters which took raw milk from individual cows and those of animals which had retail milk (Table 2 ).

\section{Discussion}

Milk is globally the most consumed food and a rich source of bioactive compounds. In recent years, special note has been paid to the hazard of different reproductive disorders caused by drinking milk $(2,26,32,36)$.

The influence of oestrogens from milk on reproductive health was studied in animal models (rats, mice and hamsters) $(6,7,9,10,15,22,28,37)$. The results of these studies are inconsistent because they are based on the testing of only one or two milk samples. Therefore, five samples from individual cows and four samples of milk purchased from retailers were studied. The study showed that there were no differences in the parameters studied in the females drinking raw milk from individual cows versus females drinking commercial milk. Additionally, a lack of oestrogenic activity in raw milk from individual animals was found. The results of the study are consistent with those of Nielsen et al. (22), who did not find uterotrophic activity after giving experimental animals milk from individual farms. The constancy of uterine weight in the present study confirms that milk oestrogens did not reach the systemic blood circulation at levels that could cause biological effects. In contrast to Nielsen et al. (22) and our study, Zhou et al. (37) and Davaasambuu et al. (7) showed oestrogenic activity of milk from individual farms. The difference between the studies' results could be caused by species-specific responses and the type and origin of the tested samples of milk. Zhou et al. (37) and Davaasambuu et al. (7) used ovariectomised rats (6 weeks old), but we used immature (15-day old) female hamsters. Two further specific divergences were that Zhou et al. (37) used sterilised samples of milk from Holstein cows; our study was performed on samples of raw (unsterilised) milk from Polish Black-and-White cows.

Besides finding raw milk not to have oestrogenically active contents at a level to produce effect, the study found the same for retail milk. The result is consistent with the study of Li et al. (15) which did not show differences in reproductive or histological parameters between a study group of rats that were fed retail milk and a control group of rats that were fed artificial milk without oestrogens. This outcome suggests that oestrogens present in retail milk did not impact reproductive functions. Likewise, Furnari et al. (9) did not find uterotrophic effects in rats after administration of commercial milk. A study performed in recent years assessed the potential effects of milk with defined concentrations of oestrogens (10). No uterotrophic effect of the hormones in the milk was found on ovariectomised mice, and notably was no effect on the group drinking milk from cows in late pregnancy with high contents of oestrogens. Furthermore, milk spiked so as to exceed the endogenous oestrogens content one-hundred-fold did not have any effect on uterus or ovary weights. However, a one-thousand-fold excess of estradiol and estrone in milk increased reproductive organ weights in females. The study indicated that oestrogens do pass from milk into the blood, but to exert some impact on reproductive organs their concentrations must surpass the endogenous concentration of hormones in milk by more than a hundred times (10). In a further demonstration of Davaasambuu et al. (6) he conducted a study of rat reproduction on two generations to investigate the generational effects of milk feeding with regard to female sex hormones. Neither generation tested bore any reproductive parameter effects.

In addition to endooestrogens, milk may contain a number of structurally diverse xenooestrogens. Depending on their concentrations, these compounds may have hormonal (oestrogenic or anti-oestrogenic) activity $(33,34)$. Such activity was exerted by synthetic oestrogens such as oestradiol esters, ethinyloestradiol, dienoestrol, hexoestrol and diethylstilboestrol when they were used illegally. In addition, plant phytoestrogens (equol, coumoestrol, daidzein and genistein) and mycooestrogens (zearalenone and its metabolites) in cattle feed can be present in milk $(1,3)$. Some studies showed the phytooestrogen genistein to increase growth in oestrogen-sensitive cells at low concentrations, but at high concentrations to decrease cell growth by inhibition of DNA synthesis and lead to cell death $(16,30)$. Furthermore, environmental pollutants can contaminate milk: endocrine residues, active pesticides, polycyclic aromatic polychlorinated hydrocarbons, biphenyls, bisphenol A, and 2-isopropylthioxanthone may cause milk to be oestrogenically or anti-oestrogenically active (34). A significant problem with commercial food products is content of compounds arising during their processing or leaching out of their packaging $(4,29,35)$. The combination of different compounds present in milk can significant changes in uterine weight. The study showed a reduction in dry uterine weight in two groups drinking commercial milk and one group receiving milk raw from the cow. The level of hormonally active compounds in milk can vary greatly, which may explain the large differences between the results of various pieces of research suggesting protective, neutral or even harmful effects of milk consumption in relation to the 
risk of hormonal disorders. The broadly ranging nature of milk samples' hormonal activity strengths validates the discordant research results even without considering individual differences in disease development and milk metabolism.

It is important to assess the potential harmful effects of milk on human health based on the study of endocrine disruptions of a mixture of xenooestrogens. Human epidemiological studies and further experiments on animals should be conducted providing long-time exposure to a mixture of exogenous substances, and their additive effects should be a topic for further studies. Based on the study, it is reasonable to conclude that the evaluated milk did not show an oestrogenic effect. However, there may have been some hormonal activity of the milk which is reflected in the decrease in dry uterine weights in this study. The contribution of milk intake to the appearance of human reproductive disorders is not clear, and since there are no general conclusions, this problem remains a subject of discussion. Taking into account that milk is a nutritive food product that delivers health benefits, research effort must be invested to avoid risk to its consumers.

Conflict of Interests Statement: The authors declare that there is no conflict of interests regarding the publication of this article.

Financial Disclosure Statement: The study was carried out as part of the statutory activities of the National Veterinary Research Institute in Puławy, Poland.

Animal Rights Statement: The study was approved by the Second Local Ethics Committee in Lublin (Resolution No. 101/2015, 8 December 2015).

\section{References}

1. Adler S.A., Purup S., Hansen-Møller J., Thuen E., Steinshamn H.: Phytoestrogens and Their Metabolites in Bulk-Tank Milk: Effects of Farm Management and Season. PLoS One 2015, 10, e0127187, doi: 10.1371 /journal.pone.0127187.

2. Afeiche M.C., Bridges N.D., Williams P.L., Gaskins A.J., Tanrikut C., Petrozza J.C., Hauser R., Chavarro J.E.: Dairy intake and semen quality among men attending a fertility clinic. Fertil Steril 2014, 101, 1280-1287, doi: 10.1016/j.fertnstert. 2014.02.003.

3. Becker-Algeri T.A., Castagnaro D., de Bortoli K., de Souza C., Drunkler D.A., Badiale-Furlong E.: Mycotoxins in Bovine Milk and Dairy Products: A Review. J Food Sci 2016, 81, R544-552, doi: 10.1111/1750-3841.13204.

4. Casajuana N., Lacorte S.: New methodology for the determination of phthalate esters, bisphenol A, bisphenol A diglycidyl ether, and nonylphenol in commercial whole milk samples. J Agric Food Chem 2004, 52, 3702-3707, doi: 10.1021/jf040027s.

5. Davaasambuu G., Cui X., Feskanich D., Hankinson S.E., Willett W.C.: Milk, dairy intake and risk of endometrial cancer: a 26-year follow-up. Int J Cancer 2012, 130, 2664-2671, doi: $10.1002 /$ ijc. 26265 .

6. Davaasambuu G., Qin L.-Q., Wang P.-Y., Tezuka H., Teramoto S., Sato A.: A two-generation reproduction study to assess the effects of cows' milk on reproductive development in male and female rats. Fertil Steril 2004, 82, 1106-1114, doi: 10.1016/j.fertnstert.2004.05.073.

7. Davaasambuu G., Tezuka H., Davaasambuu E., Hoshi K., Sato A.: Commercial cows' milk has uterotrophic activity on the uteri of young ovariectomized rats and immature rats. Int J Cancer 2005, 118, 2363-2365, doi: 10.1002/ijc.21659.

8. Diamanti-Kandarakis E., Bourguignon J.-P., Giudice L.C., Hauser R., Prins G.S., Soto A.M., Zoelelr R.T., Gore A.C.: Endocrinedisrupting chemicals: an Endocrine Society scientific statement. Endocr Rev 2009, 30, 293-342, doi: 10.1210/er.2009-0002.

9. Furnari C., Maroun D., Gyawali S., Snyder B.W., Davis A.M.: Lack of biologically active estrogens in commercial cow milk. J Dairy Sci 2012, 95, 9-14, doi: 10.3168/jds.2011-4365.

10. Grgurevič N., Koračin J., Majdič G., Snoj T.: Effect of dietary estrogens from bovine milk on blood hormone levels and reproductive organs in mice. J Dairy Sci 2016, 99, 6005-6013, doi: 10.3168/jds.2015-10610.

11. Hartmann S., Lacorn M., Steinhart H.: Natural occurrence of steroid hormones in food. Food Chem 1998, 62, 7-20, doi: 10.1016/S0308-8146(97)00150-7.

12. Hendry W.J. III., Sheehan D.M., Khan S.A., May J.V.: Developing a laboratory animal model for perinatal endocrine disruption: the hamster chronicles. Exp Biol Med (Maywood) 2002, 227, 709-723, doi: 10.1177/153537020222700904.

13. Jensen M.N., Ritskes-Hoitinga M.: How isoflavone levels in common rodent diets can interfere with the value of animal models and with experimental results. Lab Anim 2007, 41, 1-18, doi: 10.1258/002367707779399428.

14. Kang K.-S., Kim H.-S., Ryu D.-Y., Che J.-H., Lee Y.-S.: Immature uterotrophic assay is more sensitive than ovariectomized uterotrophic assay for the detection of estrogenicity of $p$-nonylphenol in Sprague-Dawley rats. Toxicol Lett 2000, 118, 109-115, doi: 10.1016/s0378-4274(00)00272-1.

15. Li X.-M., Davaasambuu G., Qin L.-Q., Sato A.: Testing potential effects of environmental endocrine disruptors in cow milk on reproductive index in female rats. Biomed Environ Sci 2005, 18, 307-313.

16. Maggiolini M., Bonofiglio D., Marsico S., Panno M.L., Cenni B., Picard D., Andò S.: Estrogen receptor $\alpha$ mediates the proliferative but not the cytotoxic dose-dependent effects of two major phytoestrogens on human breast cancer cells. Mol Pharm 2001, 60, 595-602.

17. Malekinejad H., Scherpenisse P., Bergwerff A.A.: Naturally occurring estrogens in processed milk and in raw milk (from gestated cows). J Agric Food Chem 2006, 54, 9785-9791, doi: 10.1021/jf061972e.

18. Maruyama K., Oshima T., Ohyama K.: Exposure to exogenous estrogen through intake of commercial milk produced from pregnant cows. Pediatr Int 2010, 52, 33-38, doi: 10.1111/j.1442200X.2009.02890.x.

19. Minta M., Radko L., Stypuła-Trębas S., Woźniak B., Żmudzki J.: Influence of dietary soy isoflavones on immature hamster uterotrophic and Hershberger assays. Bull Vet Inst Pulawy 2013, 57, 579-585, doi: 10.2478/bvip-2013-0099.

20. Moorman P.G., Terry P.D.: Consumption of dairy products and the risk of breast cancer: a review of the literature. Am J Clin Nutr 2004, 80, 5-14, doi: 10.1093/ajen/80.1.5.

21. Nelson R.: Steroidal oestrogens added to list of known human carcinogens. Lancet 2002, 360, 2053, doi: 10.1016/S01406736(02)12045-9.

22. Nielsen T.S., Nørgaard J.V., Purup S., Fretté X.C., Bonefeld-Jørgensen E.C.: Estrogenic activity of bovine milk high or low in equol using immature mouse uterotrophic responses and an estrogen receptor transactivation assay. Cancer Epidemiol 2009, 33, 61-68, doi: 10.1016/j.canep.2009.04.003.

23. Organization for Economic Co-operation and Development: Test Guideline 440. Uterotrophic Bioassay in Rodents: a short-term screening test for oestrogenic properties. OECD, Paris, 2007.

24. Padilla-Banks E., Jefferson W.N., Newbold R.R.: The immature mouse is a suitable model for detection of estrogenicity in the 
uterotrophic bioassay. Environ Health Perspect 2001, 109, 821-826, doi: 10.1289/ehp.01109821.

25. Pape-Zambito D.A., Magliaro A.L., Kensinger R.S.: 17Beta-estradiol and estrone concentrations in plasma and milk during bovine pregnancy. J Dairy Sci 2008, 91, 127-135, doi: 10.3168/jds.2007-0481.

26. Qin L.-Q., Xu J.-Y., Wang P.-Y., Kaneko T., Hoshi K., Sato A.: Milk consumption is a risk factor for prostate cancer: metaanalysis of case-control studies. Nutr Cancer 2004, 48, 22-27, doi: 10.1207/s15327914nc4801 4.

27. Radko L., Minta M., Jasik A., Stypuła-Trębas S., Żmudzki J.: Usefulness of immature golden hamster (Mesocricetus auratus) as a model for uterotrophic assay. Bull Vet Inst Pulawy 2015, 59, 533-539, doi: 10.1515/bvip-2015-0080.

28. Radko L., Minta M., Stypuła-Trębas S.: Estrogenic activity of commercial milk as revealed in immature hamster uterotrophic assay - pilot study. Rocz Panstw Zakl Hig 2017, 68, 303-307.

29. Raecker T., Thiele B., Boehme R.M., Guenther K.: Endocrine disrupting nonyl- and octylphenol in infant food in Germany: considerable daily intake of nonylphenol for babies. Chemosphere 2011, 82, 1533-1540, doi: 10.1016/j.chemosphere.2010.11.065.

30. Seo H.S., DeNardo D.G., Jacquot Y., Laïos I., Vidal D.S., Zambrana C.R., Leclercq G., Brown P.H.: Stimulatory effect of genistein and apigenin on the growth of breast cancer cells correlates with their ability to activate ER alpha. Breast Cancer Res Treat 2006, 99, 121-134, doi: 10.1007/s10549-006-9191-2.
31. Snoj T.: Hormones in food as a potential risk for human reproductive and health disorders. Acta Vet-Beograd 2019, 69, 137-152, doi: 10.2478/acve-2019-0011.

32. Snoj T., Majdič G.: Estrogens in consumer milk: is there a risk to human reproductive health? Eur J Endocrinol 2018, 179, 275-286, doi: 10.1530/EJE-18-0591.

33. Stypuła-Trębas S., Minta M., Radko L., Posyniak A.: Assessment of the estrogenic activity of milk and milk products with the use of in vitro estrogen receptor transactivation bioassay (in Polish). Med Srod 2017, 20, 44-48, doi: 10.19243/2017305.

34. Stypuła-Trębas S., Minta M., Radko L., Żmudzki J.: Application of the yeast-based reporter gene bioassay for the assessment of estrogenic activity in cow's milk from Poland. Environ Toxicol Pharmacol 2015, 40, 876-885, doi: 10.1016/j.etap.2015.09.022.

35. ter Veld M.G.R., Schouten B., Louisse J., van Es D.S., van der Saag P.T., Rietjens I.M.C.M., Murk A.J.: Estrogenic Potency of Food-Packaging-Associated Plasticizers and Antioxidants As Detected in ER $\alpha$ and ER $\beta$ Reporter Gene Cell Lines. J Agric Food Chem 2006, 54, 4407-4416, doi: $10.1021 / \mathrm{jf052864f}$

36. Wiley A.S.: Milk Intake and Total Dairy Consumption: Associations with Early Menarche in NHANES 1999-2004. PLoS One 2011, 6, e14685, doi: 10.1371/journal.pone.0014685.

37. Zhou H., Qin L.-Q., Ma D.-F., Wang Y., Wang P.-Y.: Uterotrophic effects of cow milk in immature ovariectomized Sprague-Dawley rats. Environ Health Prev Med 2010, 15, 162-168, doi: 10.1007/s12199-009-0123-8. 